\title{
KONSEPTUALISASI PENDIDIKAN KARAKTER BERBASIS PEMBENTUKAN AKHLAK DI PESANTREN
}

\author{
Idhar \\ SekolahTinggi IlmuTarbiyah (STIT) Sunan Giri Bima \\ idharrato123@email com
}

\begin{abstract}
Abstrak
Pesantren merupakan lembaga pendidik, tidak hanya mendidik para santri ilmu agama, melainkan juga membekalinya dengan akhlak yang menjadi karakter khas dari seorang santri. Tidak berlebihan ketika pesantren dikatakan sebagai sumber pendidikan karakter untuk menjawab persoalan bangsa. Kasus yang banyak terjadi pada siswa ialah karena kurangnya pendidikan karakter pada diri siswa. Ciri khas pesantren dan sangat sulit ditiru oleh lembaga pendidikan lainnya adalah kuatnya penanaman akhlakakhlak terpuji. Sehingga label 'santri' pun secara dzahir telah identik dengan keshalehan, baik itu secara individu maupun sosial. Hal ini wajar, karena pembiasaan aplikasi akhlak terpuji telah mendarah daging dalam dunia pendidikan pondok pesantren. Kyai sebagai sentral figur di dalamnya memberikan uswah dan qudwah hasanah dalam pendidikan akhlak. Karena penanaman akhlak lebih mengena dengan perbuatan daripada penjejalan materi di dalam kelas, maka pendidikan akhlak di pondok pesantren sangat mengena di benak para santrinya.
\end{abstract}

Kata Kunci: Pendidikan Pesantren, Nilai-Nilai Akhlak

\section{Pendahuluan}

$\mathbf{S}$ ecara spesifik bahwa krisis multi dimensi yang melanda Indonesia bersumber pada menurunnya kualitas akhlak yang baik, maka kualitas akhlak tersebut akan muncul dalam bentuk sikap dan perilaku yang baik.Tetapi kenyataan yang terjadi pada pendidikan Indonesia saat ini sungguh memprihatinkan. Banyak kasus pelajar saat ini tidak mencerminkan sikap sebagai "kaum terpelajar" seperti peristiwa tawuran yang tak kunjung selesai, belum lagi kasus narkoba, tindakan asusila dan bahkan melibatkan gurunya sendiri. Hal tersebut sudah menjadi masalah sosial yang sampai saat ini belum dapat diatasi. Padahal, dalam undang-undang tentang sistem pendidikan dijelaskan bahwa tujuan dari pendidikan ialah meningkatkan keimanan dan ketakwaan serta akhlak mulia dalam rangka mencerdaskan kehidupan bangsa, yang diatur dengan undangundang (Pasal 31 ayat 3). Bahkan konten pasal ini menegaskan bahwa tujuan dari pendidikan di Indonesia adalah bertujuan meningkatkan keimanan dan ketakwaan serta ahlak mulia dalam diri seorang peserta didik. Meskipun pada realitasnya, sistem pengajaran yang diberikan sekolah terhadap siswanya sebagian besar ialah hanya berorientasi kepada kecerdasan intelektual semata (intellectual 
intelegense) sedangkan penanaman nilai-nilai karakter (character values) pada diri siswa sangat kurang sekali.

Namun yang terpenting, dalam menerapkan pendidikan tersebut, anak didik bukan hanya dituntut memahami pengetahuan tentang akhlak semata, melainkan mengharapkan mereka dapat menerapkan dan mengaplikasikan pengetahuan tersebut dalam kehidupan sehari-hari. Hal ini dikarenakan sikap seseorang tidak hanya cukup diukur dari seberapa jauh anak menguasai hal-hal yang bersifat kognitif semata. Justru yang lebih penting ialah seberapa besar nilainilai itu terwujud dalam tingkah laku sehari-hari akan melahirkan budi pekerti yang luhur (akhlakul karimah). ${ }^{1}$ Selain itu, perkembangan kepribadian manusia juga sangat dipengaruhi oleh bagaimana pendidikan dan pengalaman yang telah dialami di dalam kehidupannya untuk bermasyarakat dan bernegara. Dengan kesadaran manusia untuk berkembang dan pertumbuhan adalah merupakan suatu sifat yang dimiliki oleh manusia itu sendiri, sehingga mereka selalu tumbuh dan mencari kebahagiaan untuk mendapatkan keserasian dan kesehatan baik jasmaninya maupun rohaninya. ${ }^{2}$

Sebagai lembaga pendidikan, pesantren tidak hanya mendidik para santri ilmu agama, melainkan juga membekalinya dengan akhlak yang menjadi karakter khas dari seorang santri. Karena itu, tidak berlebihan ketika pesantren dikatakan sebagai sumber pendidikan karakter untuk menjawab persoalan bangsa. Kasus yang banyak terjadi pada siswa ialah karena kurangnya pendidikan karakter pada diri siswa. Dalam institusi pesantren ketika ada seorang santri yang pertama masuk bukan langsung dididik dengan ilmu-limu pengetahuan seperti ilmu nahwu, sorof, balaghoh, mantiq dan bayan tetapi para santri terlebih dahulu diajari adab sopan santun dan ketakdziman terhadap sang kiai, dan biasanya kitab yang pertama kali adalah kitab Ta'lim al Muta'alim. Dalam kitab tersebut memuat tentang adab seorang santri ketika belajar. Sehingga nilai-nilai akhlak inilah yang dapat mengurangi potensi tawuran diantara para santri, mencegah tindakan para santri yang dapat mengancam gurunya maupun santri yang terlibat pergaulan bebas dan narkoba.

Dalam persepektif pendidikan Islam Indonesia, pendidikan pondok pesantren merupakan bagian tak terpisahkan dari pendidikan nasional yang memberikan pencerahan bagi peserta didik secara integral, baik kognitif (knowledge), afektif (attitude) maupun psikomotorik (skill) yang memiliki prinsip panca jiwa, yakni keikhlasan, kesederhanaan, kemandirian, ukhuwah islamiyah dan kebebasan. Oleh karena itu pondok pesantren sebagai lembaga pendidikan agama tertua di Indonesia dan telah menunjukkan kemampuannya dalam mencetak kader-kader ulama dan telah turut berjasa dalam mencerdaskan

\footnotetext{
${ }^{1}$ A. Malik Fadjar, Reorentasi Pendidikan Islam (Jakarta: Fajar Dunia, 1999), 13.

${ }^{2}$ Sattu Alang, Kesehatan MentalDan Terapi Islam ( Makassar:Berkah Utami, 2005), 118.
} 
masyarakat. Bahkan pesantren sebagai lembaga pendidikan pertama di Indonesia telah banyak melahirkan generasi-generasi emas, pondok pesantern telah menorehkan tinta emas dalam peradaban sejarah bangsa indonesia. Pesantren bukan saja lembaga tempat mencari dan menuntut ilmu tetapi juga tempat penggemblengan karakter pada diri santri, ketika lulus dari pesantren sang santri tersebut diharapkan dapat menerapkan ilmu pengetahuan dan dapat memberikan contoh dan teladan bagi masyarakat. Hal ini yang tidak terdapat dalam pendidikan umum, sekolah-sekolah dan perguruan tinggi. Dalam hal ini bukan berarti penulis menghendaki semua metode pesantren diterapkan dalam lingkungan sekolah. Penerapan pendidikan karakter yang diberlakukan pada pondok pesantren tentu saja dengan adanya penyesuaian adaptasi dan disesuaikan dengan perkembangan zaman supaya tidak terlihat kaku dan kuno.

\section{Konsep Pendidikan Karakter dalam Pesantren}

Keberadaan pesantren sebagai basis lembaga pendidikan keagamaan, telah memposisikan pesantren menjadi lembaga pendidikan yang identik dengan pembentukan karakter peserta didik. Sehubungan dengan hal tersebut, menelusuri proses pembelajaran dalam pendidikan pesantren, sejatinya akan ditemukan bahwa aspek pembelajaran peserta didik sangat menekankan nilai-nilai akhlak/budi pekerti peserta didik sebagai landasan utama bagi para santri dalam proses pembelajaran. Bahkan pendidikan tentang pentingnya akhlak dalam rutinitas para santri teramsuk hal paling utama yang dikembangkan dalam pola interaksi dalam pendidikan dipesantren, mulai dari akhlak kepada para guru (kiai), akhlak kepada teman sejawat, termasuk akhlak dalam proses pembelajaran. Berkaitan dengan itu, pendidikan akhlak/budipekerti menurut Athiyah al-Abrasyi dengan merujuk rumusan Badan Pertimbangan Pendidikan Nasional diartikan sebagai sikap dan prilaku sehari-hari baik individu, keluarga, maupun masyarakat, bangsa yang mengandung nilai-nilai yang berlaku dan dianut dalam bentuk jati diri, nilai persatuan dan kesatuan, integritas, dan kesinambungan masa depan dalam suatu sistem moral, yang menjadi pedoman prilaku manusia Indonesia untuk bermasyarakat, berbangsa dan bernegara dengan bersumber pada falsafah Pancasila dan diilhami oleh ajaran agama serta budaya Indonesia. ${ }^{3}$

Dalam konteks Agama Islam, budi pekerti digunakan untuk menyatakan akhlak, tabiat, perangai, tingkah laku seorang. Secara umum gabungan dari kedua pengertian di atas, seperti yang dirumuskan pemakanaan tentang budi pekerti yang diartikan sebagai kesusilaan yang mencakup segi-segi kejiwaan dan perbuatan manusia: sedangkan manusia susila adalah manusia yang sikap lahiriah dan batiniyahnya sesuai dengan norma etika dan moral. Pengertian yang telah dikemukakan di atas, mengindikasikan bahwa budi pekerti mengacu pada sikap

${ }^{3}$ Athiyah al-Abrasyi, Dasar Dasar Pokok Pendidikan Islam (Jakarta: Bulan Bintang, 1993), 211 
dan prilaku seseorang maupun masyarakat yang mengedepankan norma dan etika. Pendidikan budi pekerti adalah usaha sadar penanaman/internalisasi nilai-nilai akhlak/ moral dalam sikap dan prilaku manusia peserta didik agar memiliki sikap dan prilaku yang luhur (akhlakul karimah) dalam keseharian baik dalam berinteraksi dengan Tuhan, dengan sesama manusia dan dengan alam lingkungan. ${ }^{4}$ Selanjutnya, dilihat dari fungsi dan peranannya seperti etika, susila dan akhlak sama, yaitu menentukan hukum atau nilai dari suatu perbuatan yang dilakukan manusia untuk ditentukan baik buruknya. ${ }^{5}$ Sebenarnya kesemuanya itu mengharapkan terbentuknya keadaan mansyarakat yang baik, teratur, tentram, aman, damai dan sejahtera lahir dan bathin.

Akhlak bukan saja tata aturan atau norma perilaku yang mengatur hubungan antara sesama manusia dengan tuhan dan bahkan dengan alam semesta sekalipun. ${ }^{6}$ Akhlak secara bahasa bisa baik dan bisa buruk tergantung tata nilai yang dipakai sebagai landasannya, meskipun secara sosiologis di Indonesia kata akhlak sudah digantung konotasi baik, jadi orang yang berakhlak berarti orang yang berakhlak baik. ${ }^{7}$

Menurut Sattu Alang mengatakan "akhlak adalah perbuatan yang dilakukan secara pontanitas, yang timbul karena dorongan emosi jiwanya, bukan karena adanya tekanan-tekanan yang datang dari luar. ${ }^{8}$ Akhlak adalah suatu kondisi atau sifat yang telah meresap dalam jiwa dan telah menjadi kepribadian, dengan timbulnya berbagai macam perbuatan tanpa perencanaan. Sekalipun definisi netral, belum menunjukan kepada baik dan buruk, tetapi pada umumnya bila kata tersebut sendirian dan tidak dirangkai dengan kata tertentu, maka dimaksud dengan akhlak yang baik (mulia). Contohnya bila seorang berlaku tidak sopan maka dikatakan kepadanya "kamu tidak berakhlak" atau dikatakan "kurang ajar" padahal tidak sopan dan kurang ajar itu adalah akhlaknya dalam hal ini tidak sopan santun.

\section{Pengembangan Pendidikan Karakter Dalam Pesantren}

Pondok pesantren adalah salah satu lembaga pendidikan yang memiliki ciri-ciri khas yang tidak dimiliki oleh lembaga pendidikan lainnya di dunia. Salah satu kekhasan yang dimilikinya adalah melekatnya peran para kyai sebagai tokoh sentral di dalamnya. Mereka mendapatkan keistimewaan lebih karena biasanya kyai adalah pendiri atau keturunan dari pendiri pondok pesantren yang dengan ikhlas tanpa pamrih membangun pondok pesantren untuk kemajuan ummat.

${ }^{4}$ Dosen Fakultas Tarbiyah, Laporan Penelitian Pendidikan Budi Pekerti Pada Sekolah Model (Jakarta: Pustaka kampus, 2001), 118.

${ }^{5}$ Abuddin Nata, Akhlak Tasawuf (Ed. I Jakarta: Grafindo Persada, 2009), 240.

${ }^{6}$ Ilyas Yunahar, Kuliah Akhlak (Cet. VIII; Yogyakarta: LPPI UMY, 2006), 1.

${ }^{7}$ Zakiah Daradjat, Dasar-Dasar Agama Islam (Cet. 11 Makassar: Berkah Utami, 2005), 99.

${ }^{8}$ Sattu Alang, Kesehatan Mental dan Terapi Islam (Cet. II; Makassar: Berkah Utami, 2005), 99. 
Jarang dari mereka yang memiliki ambisi duniawi ketika membangun fondasi pondok pesantren. Peran penting kyai dalam pendirian, pertumbuhan, perkembangan dan pengurusan sebuah pesantren berarti dia merupakan unsur yang paling esensial. Sebagai pemimpin pesantren, watak dan keberhasilan pesantren banyak bergantung pada keahlian dan kedalaman ilmu, karismatik, dan wibawa, serta keterampilan kyai. Dalam konteks ini, pribadi kyai sangat menentukan sebab dia adalah tokoh sentral dalam pesantren. ${ }^{9}$

Istilah kyai bukan berasal dari bahasa Arab, melainkan dari bahasa Jawa. Dalam bahasa Jawa perkataan kyai dipakai untuk tiga jenis gelar yang berbeda, yaitu: Pertama, sebagai gelar kehormatan bagi barang-barang yang dianggap keramat, contohnya, "kyai garadu kencana"dipakai untuk sebutkan kereta emas yang ada di Kraton Yogyakarta; Kedua sebagai gelar kehormatan bagi orang-orang tua pada umumnya; Ketiga sebagai gelar yang diberikan oleh masyarakat kepada orang ahli agama Islam yang memiliki atau menjadi pimpinan pesantren dan mengajar kitab-kitab Islam klasik kepada para santrinya. ${ }^{10}$

Sentral yang kedua yang tidak dapat dipisahkan dari pondok pesantren adalah masjid. Dalam hal ini masjid berfungsi sebagai pusat kegiatan santri, para penghuni pondok pesantren. Masjid di pesantren tidak berfungsi sekunder, yakni untuk amalan-amalan ukhrowi, tapi juga sebagai pusat ekonomi, pembelajaran, dan pemberdayaan. Maka biasanya bangunan yang pertama kali ada dalam sebuah pondok pesantren haruslah masjid, meskipun di kemudian hari tradisi ini mulai berubah.Sangkut paut pendidikan Islam dan masjid sangat dekat dan erat dalam tradisi Islam di seluruh dunia. Dahulu, kaum muslimin selalu memanfaatkan masjid untuk tempat beribadah dan juga sebagai tempat lembaga pendidikan Islam. Sebagai pusat kehidupan rohani, sosial dan politik, dan pendidikan Islam, masjid merupakan aspek kehidupan sehari-hari yang sangat penting bagi masyarakat. Dalam rangka pengembangan pendidikan pesantren, masjid dianggap sebagai "tempat yang paling tepat untuk mendidik para santri, terutama dalam praktek shalat lima waktu, khutbah, dan shalat Jumat, serta pengajaran kitab-kitab klasik" biasanya yang pertama-tama didirikan oleh seorang kyai yang ingin mengembangkan sebuah pesantren adalah masjid. Masjid itu terletak dekat atau di belakang rumah kyai. ${ }^{11}$

Pondok pesantren lekat sekali dengan pengkajian ilmu-ilmu ketuhanan. Para santri bertafaqquh fiddin agar mereka dapat menjadi penyeru bagi ummat-ummatnya. Selain itu, ilmu-ilmu kauniah pun tidak luput dari kajian mereka. Mereka belajar tauhid, fiqh, al-quran, assunah, sekaligus

\footnotetext{
${ }^{9}$ Hasbullah, Sejarah Pendidikan Islam di Indonesia: Lintasan Sejarah Pertumbuhan Dan Perkembangan (Jakarta: PT Raja Grafindo Persada, 1999), 69.

${ }^{10}$ Zamakhsyari Dhofier, Tradisi Pesantren: Studi Tentang Pandangan Hidup Kyai, (Jakarta: LP3ES, 1985), 37.

${ }^{11}$ Mujamil, Pesantren dan Transformasi Metodologi Menuju Demokratisasi Institusi (Jakarta: Erlangga, 2005), 149
} 
astronomi, fisika, biologi, kimia, ekonomi, sejarah dan disipilin ilmu lainnya. Dalam dunia pondok pesantren tidak dikenal dikotomi ilmu. Yang ada adalah kesadaran bahwa semua ilmu sumbernya satu: al-'Alim, Yang Maha Mengetahui. Tentunya ilmu ketuhanan memiliki porsi lebih, hal ini karena berkaitan dengan jenjang prioritas dalam pengklasifikasian ilmu. ${ }^{12}$

\section{Penanaman Nilai Karakter dalam Pendidikan Peasantren}

Terdapat beberapa nilai karakter yang perlu ditanamkan kepada peserta didik agar terbentuk akhlak mulia, yaitu:

\section{Niat dalam Mencari Ilmu}

Pendidikan identik dengan "mencari ilmu" atau "menuntut ilmu", maka dalam mencari ilmu pelajar harus menata niatnya ketika akan "mencari ilmu". Niat pelajar dalam menuntut ilmu harus ikhlas mengharap ridha Allah, mencari kebahagiaan di akhirat menghilangkan kebodohan dirinya. Dalam menuntut ilmu juga harus didasari niat untuk mensyukuri nikmat akal dan kesehatan badan. Jangan sampai ada niat supaya dihormati masyarakat, untuk mendapatkan harta dunia, atau agar mendapat kehormatan di hadapan pejabat atau lainnya.Boleh menuntut ilmu dengan niat dan upaya mendapat kedudukan di masyarakat kalau kedudukan tersebut digunakan untuk amar ma'ruf nahi munkar, dan untuk melaksanakan kebenaran, serta untuk menegakkan agama Allah. Bukan untuk mencari keuntungan diri sendiri, juga bukan karena keinginan hawa nafsu. Semua itu perlu direnungkan oleh para penuntut ilmu, supaya ilmu yang mereka cari dengan susah payah tidak sia-sia. Oleh karena itu dalam mencari ilmu jangan dilandasi niat untuk mencari dunia yang hina dan fana. ${ }^{13}$

\section{Penghormatan Terhadap Ilmu dan Guru}

Para pelajar tidak akan memperoleh ilmu dan tidak akan dapat mengambil manfaatnya, tanpa mau menghormati ilmu dan guru. Berikut beberapa bentuk penghormatan terhadap guru (1) hendaknya seorang murid tidak berjalan di depannya (2) tidak duduk ditempatnya (3) tidak memulai berbicara padanya kecuali atas ijinnya. Sedangkan bentuk penghormatan terhadap ilmu diantaranya : (1) menghormati teman dan orang yang mengajar (2) mendengarkan apa yang disampaikan oleh guru dengan rasa hormat, sekalipun sudah pernah mendengarkan sebelumnya.

\section{Kesungguhan dalam Mencari Ilmu}

Dalam mencari ilmu modal yang diperlukan ialah kesungguhan. Segala sesuatu bisa dicapai asal mau bersungguh-sungguh dan bercita-cita luhur. Jika ada yang bercita-cita ingin pandai, tapi tidak mau bersungguh-sungguh dalam belajar, tentu dia tidak akan memperoleh ilmu kecuali sedikit. Adapun sifat malas itu

43.

${ }^{12}$ Syaikh Az-Zarnuji, Terjemahan Ta'lim Muta'allim (Surabaya : Mutiara Ilmu, 2012),

${ }^{13}$ Ibid. 
timbul karena kurangnya perhatian terhadap keutamaan dari pentingnya ilmu. Sebagaimana dikatakan oleh Ali bin Abi Thalib "Aku senang menerima pemberian Tuhan Maha Kuasa, kita diberi ilmu dan musuh-musuh kita (orangorang kafir)diberi harta benda. Karena harta akan segera sirna, sedang ilmu itu abadi takkan pernah hilang".

Ilmu yang bermanfaat akan tetap dikenang sekalipun orang yang berilmu itu meninggal, karena ilmu yang bermanfaat itu abadi, Syaikh Murghinan berkata dalam sebuah syair : "orang bodoh hakikatnya mati sebelum mati, dan orang berilmu tetap hidup sekalipun sudah mati."14

\section{Senantiasa Melakukan Diskusi Pembelajaran}

Para pelajar harus sering mendiskusikan suatu pendapat atau masalah dengan teman-temannya. Diskusi tersebut harus dilakukan dengan tertib atau tenang. Tidak gaduh, tidak emosi. Karena tertib dan tenang dalam berfikir adalah tiangnya musyawarah. Dan tujuan musyawarah adalah mencari kebenaran. Tujuan itu akan tercapai bila orang-orang yang terlibat dalam diskusi atau musyawarah tersebut bersikap tenang, benar dalam berfikir dan lapang dada. Sebaliknya, hal itu tidak akan berhasil bila timbul kegaduhan dan saling emosi.Adapun tujuan diadakannya diskusi tersebut untuk saling mengalahkan hujah temannya, maka tidak diperbolehkan, diskusi itu diperbolehkan kalau tujuannya untuk mencari kebenaran, sedangkan mengaburkan persoalan atau jawaban, atau membenci tanggapan dengan cara yang tidak semestinya, juga tidak diperbolehkan. Kecuali jika orang yang bertanya itu bermaksud mempersulit, tidak mencari kebenaran.Dalam diskusi harus senang mengamati atau memikirkan pelajaranpelajaran yang sukar dipahami, dan harus membiasakan hal itu. Karena banyak orang bisa mengerti setelah ia mau memikirkan. Oleh karena itu ada yang berkata, "perhatikanlah niscaya kamu akan mengerti". Sebelum berbicara, harus berpikir dulu, supaya ucapannya benar, karena ucapan itu bagaikan anak panah, oleh karena itu harus diluruskan atau dipikir dulu sebelum berbicara, agar tidak salah.

\section{Berusaha Mencari Tambahan Ilmu}

Para pelajar harus menambah ilmu setiap hari agar mendapat kemuliaan. Harus selalu membawa buku dan pulpen, untuk menulis ilmu yang bermanfaat yang ia dengar setiap saat. Karena ilmu yang dihafal suatu ketika bisa lupa. Sedang ilmu yang ditulis akan tetap abadi. Ada yang berkata, "ilmu itu sesuatu yang diambil dari mulut orang-orang pandai karena mereka itu menghafal sebaik-baik yang mereka dengar. Dan mengatakan sebaik-baik yang mereka hafal'.Pelajar harus bisa memanfaatkan kesempatan bersama para guru. Gunakan untuk menimba pengetahuan dari mereka. Karena kesempatan yang baik apabila telah hilang, tidak akan dijumpai lagi. Pelajar harus tahan menanggung 2012), 43.

${ }^{14}$ Syaikh Az-Zarnuji. (2012). Terjemahan Ta'lim Muta'allim. (Surabaya : Mutiara Ilmu, 
penderitaan dan kehinaan ketika mencari ilmu. Ada yang berkata "ilmu itu luhur, tiada hina padanya. Namun ilmu tak bisa didapat kecuali dengan merendah".

\section{Memiliki sifat Wara}

Sebagian ulama meriwayatkan sebuah hadits, dari Rasulullah SAW bersabda : "Barangsiapa tidak berlaku wara' ketika belajar ilmu, maka dia akan diuji oleh Allah dengan salah satu dari tiga macam ujian, mati muda, ditempatkan bersama orang-orang bodoh, atau diuji menjadi pelayan pemerintah.'Pelajar yang bersifat wara' ilmunya lebih bermanfaat. Belajarnya lebih mudah. Termasuk sifat wara' ialah menghindari rasa kenyang, banyak tidur, dan banyak bicara yang tidak berguna. Termasuk wara' adalah menyingkir dari orang yang suka berbuat kerusakan dan maksiat. Serta senang menganggur. Karena bergaul dengan orang seperti itu bisa terpengaruh. Ketika belajar hendaknya menghadap ke kiblat. ${ }^{15}$

\section{Penutup}

Pesantren sebagai lembaga pendidikan pertama di Indonesia telah banyak melahirkan generasi-generasi emas, pondok pesantren telah menorehkan tinta emas dalam peradaban sejarah bangsa Indonesia. Pesantren bukan saja lembaga tempat menuntut ilmu tetapi juga tempat penggemblengan karakter pada diri santri. Ketika lulus dari pesantren, sang santri diharapkan dapat menerapkan ilmu pengetahuan dan dapat menjadi contoh dan teladan bagi masyarakat. Hal ini yang tidak terdapat dalam pendidikan umum, sekolah sekolah dan perguruan tinggi. Dalam hal ini bukan berarti penulis menghendaki semua metode pesantren diterapkan dalam lingkungan sekolah. Penerapan pendidikan karakter yang ada dalam pesantren diberlakukan pada pondok pesantren tentu saja dengan adanya penyesuaian (adaptasi) dan disesuaikan dengan perkembangan jaman supaya tidak terlihat kaku dan kuno. Penanaman nilai-nilai dalam menuntut ilmu diantaranya : (1) niat menuntut ilmu harus ikhlas mengharap ridha Allah, mencari kebahagiaan di akhirat menghilangkan kebodohan dirinya; (2) hormat terhadap guru dan hormat terhadap ilmu (3) dalam mencari ilmu modal yang diperlukan ialah kesungguhan; (4) para pelajar harus sering mendiskusikan suatu pendapat atau masalah dengan teman-temannya; (5) Pelajar harus bisa memanfaatkan kesempatan bersama para guru; (6) Rendah hati terhadap ilmu yang ia pelajari. 


\section{DAFTAR PUSTAKA}

Al-Abrasyi, Athiyah.Dasar Dasar Pokok Pendidikan Islam. Jakarta: Bulan Bintang, 1999

Alang,Sattu.Kesehatan Mental Dan Terapi Islam. Makassar:Berkah Utami, 2005.

Az-Zanuji, Syaikh.Terjemahan Ta'lim Muta'allim. Surabaya: Mutiara Ilmu, 2012.

Daradjat, Dakiah. Dasar-Dasar Agama Islam. Makassar: Berkah Utami, 2005.

Dhofier,Zamakhsyari.Tradisi Pesantren: Studi Tentang Pandangan Hidup Kyai. Jakarta: LP3ES, 1985.

Fadjar,A. Malik.Reorentasi Pendidikan Islam.Jakarta: Fajar Dunia, 1999.

Fakultas Tarbiya. Laporan Penelitian Pendidikan Budi Pekerti Pada Sekolah Model, Jakarta: Pustaka kampus, 2001.

Hasbullah.Sejarah Pendidikan Islam di Indonesia: Lintasan Sejarah Pertumbuhan Dan Perkembangan. Jakarta: PT Raja Grafindo Persada, 1999.

Ilyas, Yuhanar. Kuliah Akhlak. VIII; Yogyakarta: LPPI UMY, 2006.

Mujamil.Pesantren dan Transformasi Metodologi Menuju Demokratisasi Institusi. Jakarta: Erlangga, 2005.

Nata,Abuddin. Akhlak Tasawu, Ed. I. Jakarta: Grafindo Persada, 2009. 